IZA DP No. 6893

Wage Growth and Job Mobility in the Early Career: Testing a Statistical Discrimination Model of the Gender Wage Gap

Philippe Belley

Nathalie Havet

Guy Lacroix

October 2012 


\title{
Wage Growth and Job Mobility in the Early Career: Testing a Statistical Discrimination Model of the Gender Wage Gap
}

\author{
Philippe Belley \\ Kansas State University \\ Nathalie Havet \\ GATE Lyon-Saint-Etienne, Université de Lyon \\ Guy Lacroix \\ Université Laval, \\ CIRPÉE, CIRANO and IZA
}

\section{Discussion Paper No. 6893 \\ October 2012}

\author{
IZA \\ P.O. Box 7240 \\ 53072 Bonn \\ Germany \\ Phone: +49-228-3894-0 \\ Fax: +49-228-3894-180 \\ E-mail: iza@iza.org
}

\begin{abstract}
Any opinions expressed here are those of the author(s) and not those of IZA. Research published in this series may include views on policy, but the institute itself takes no institutional policy positions. The IZA research network is committed to the IZA Guiding Principles of Research Integrity.

The Institute for the Study of Labor (IZA) in Bonn is a local and virtual international research center and a place of communication between science, politics and business. IZA is an independent nonprofit organization supported by Deutsche Post Foundation. The center is associated with the University of Bonn and offers a stimulating research environment through its international network, workshops and conferences, data service, project support, research visits and doctoral program. IZA engages in (i) original and internationally competitive research in all fields of labor economics, (ii) development of policy concepts, and (iii) dissemination of research results and concepts to the interested public.
\end{abstract}

IZA Discussion Papers often represent preliminary work and are circulated to encourage discussion. Citation of such a paper should account for its provisional character. A revised version may be available directly from the author. 


\section{ABSTRACT}

\section{Wage Growth and Job Mobility in the Early Career: Testing a Statistical Discrimination Model of the Gender Wage Gap}

The paper focuses on the early career patterns of young male and female workers. It investigates potential dynamic links between statistical discrimination, mobility, tenure and wage profiles. The model assumes that it is more costly for an employer to assess female workers' productivity and that the noise/signal ratio tapers off more rapidly for male workers. These two assumptions yield numerous theoretical predictions pertaining to gender wage gaps. These predictions are tested using data from the 1979 cohort of the National Longitudinal Survey of Youth. As predicted by our statistical discrimination model, we find that men and women have the same wage at the start of their career, but that female wages grow at a slower rate, creating a gender wage gap. Also consistent with our model, we find that mean wages are higher for workers who keep their job, while wage growth is stronger for workers who change job.

JEL Classification: J16, J71, J41

Keywords: gender wage gap, job transitions, tenure, returns to mobility, experience

Corresponding author:

Guy Lacroix

Department of Economics

Pavillon de Sève

Université Laval

Québec (Québec)

Canada G1K 7P4

E-mail: Guy.Lacroix@ecn.ulaval.ca 


\section{Introduction}

Economic analysis has made numerous contributions to our understanding of the causes of occupational segregation and the existence of earnings disparities between men and women on the labor market. ${ }^{1}$ In particular, several theories of discrimination have attempted to explain why two groups with identical average productivity are paid different average wages. They have attributed differences to either employers' prejudices, i.e. taste discrimination [Becker (1957)], or imperfect information, i.e. statistical discrimination [Phelps (1972); Arrow (1973)]. However, all of these theories in their earliest and simplest version are not supported by empirical evidence. Models built on taste discrimination predict the elimination of the male/female differential in the long run, whereas their persistency has been observed for decades in most OECD countries. Models based on statistical discrimination have proved deceptive since they were unable to generate a gender/racial gap in mean wages.

Consequently, second generation models have been developed to go beyond the strict opposition between discrimination and productivity differentials. For example, recent models of taste discrimination integrate henceforth the dynamic of job-search costs [Flabbi (2010); Bowlus and Eckstein (2002); Rosen (2003); Black (1995); Sattinger (1996); Sasaki (1999); Sulis (2011)] and obtain more interesting conclusions in the long term. Nevertheless, these models are always little helpful in understanding gender discrimination as they fail to explain the root of the prejudices. In contrast to taste-based theories of discrimination, statistical discrimination theories derive group inequality without assuming gender animus or preference bias against members of a targeted group. Models of statistical discrimination are more appealing because they suggest gender discrimination may be a rational response by firms to imperfect information on individual productivity.

While all models of statistical discrimination share that feature, there exist important differences

\footnotetext{
${ }^{1}$ For a literature review, see Cain (1986) and, more recently, Altonji and Blank (1999) and Havet (2004) and for statistical discrimination, see Fang and Moro (2011).
} 
which suggest different explanations for group inequality. Two principal paths in this literature have been followed. The first one, based on Arrow (1973), examines how asymmetric beliefs (true or not) about different groups can influence hiring decisions or wages. Recent models of this kind combine dynamic job assignment models with human capital assumptions. They explain wage differentials as well as promotions [Lazear and Rosen (1990); Barron et al. (1993)] and their long term persistency [Coate and Loury (1993); Moro and Norman (2004); Moro (2003); Fryer (2007)].

The second path followed in the field of statistical discrimination originates directly from the pioneer work of Phelps (1972). It is based on the notion that employers are unable to precisely know the productivity of each employee insofar as the signals available to them (recruitment tests, diplomas, etc.) are less reliable for women than for men. Recent work has thus extended Phelps's seminal contribution by introducing human capital investment decisions [Lundberg and Startz (1983); Havet and Sofer (2008)] or by accounting for job matching [Rothschild and Stiglitz (1982); Oettinger (1996)]. In both cases, it turns out wage gaps arise endogenously.

This paper focuses on the early career patterns of young male and female workers. In order to achieve a better understanding of the overall gender wage gap, it seems to be of crucial importance to understand the factors contributing to the gender differential in early-career wage growth. Indeed, we empirically observe that the gender wage gap is fairly small at the entry into the labour market, but after a few years a considerable gender wage gap emerges [Loprest (1992); Manning and Swaffield (2008); Napari (2009); Del Bono and Vuri (2011)]. Consequently, investigating the determinants of gender wage gap in the early career could help understand the growing male-female wage gap over the course of the worker's career. Moreover, focusing on career starts is particularly interesting since some of the common explanations for gender wage gap are irrelevant at this stage. For example, male and female workers differ fairly little in terms of career interruptions and thus gender wage gap cannot be convincingly explained by gender differences in promotion opportunities (glass ceillings) 
given the short durations of jobs and the small experience of young workers. By contrast, models of job mobility, which point to the heterogeneity in the quality of employee-employer matches [Burdett (1978); Jovanovic (1979)] could be relevant. There is evidence that mobility plays a less important role in terms of wage growth for young women: not only are young women less likely to quit a job, but they also seem to receive lower returns to mobility than young men [Simpson (1990); Light and Ureta (1992); Loprest (1992)].

Therefore, our paper seeks to illustrate potential links between statistical discrimination, mobility, tenure and wage profiles. We use the statistical discrimination model proposed by Oettinger (1996) to explain racial wage gaps as our starting point. Thus a worker's productivity is assumed to depend on the quality of the job match. It is further assumed that it is more costly for an employer to assess female workers' productivity. Finally, the model allows productivity to become less noisy with tenure. As in Altonji and Pierret (2001) and Altonji (2005), we assume that employers learn about workers' characteristics and productivity over time. However, unlike Oettinger (1996), we assume that female workers' productivity remains noisy with tenure, while male workers' noise/signal ratio is assumed to be zero in the second period of their two-period lives.

Oettinger (1996) conjectured that even if asymmetries and informational imperfections were only transient, they could nevertheless generate permanent wage differentials between racial groups. By assuming away perfect productivity revelation for women, our model does indeed show that gender wage gaps may appear within the first years of the working lives and may be permanent. Furthermore, the model provides a simple framework within which gender differences in terms of tenure, experience and mobility can be better understood.

The model generates a series of predictions that we test against U.S. data from the 1979 cohort of the National Longitudinal Survey of Youth. It turns out most theoretical predictions are supported by the data. The paper is organized as follows. Section 2 describes the structure of the model and 
its basic assumptions. Section 3 presents the wage profiles that characterize the equilibrium and emphasizes theoretical implications with respect to gender differences in mobility. Finally, Section 4 presents the empirical results and Section 5 concludes the paper.

\section{The Structure of the Model}

Our approach is based on the dynamic statistical discrimination model setup by Oettinger (1996), which incorporates the notion of job-matching. In particular, like Oettinger, we assume that the productivity of any job match is imperfectly observed ex ante, that the initial productivity signal is noisier for the "minority" group (i.e. women in the present paper) and that additional information about the productivity of the match is revealed with tenure on the job. Our contribution is to extend Oettinger's framework by allowing for the possibility that match productivity is not revealed completely for women as job tenure accumulates and consequently female workers' productivity remains less reliable. It turns out that this simple generalization substantially expands the set of empirical predictions with respect to male-female differences in starting wages, wage levels for experienced workers and wage growth.

In our model, the agents are competitive firms who negotiate compensation with employees oneon-one and offer each a wage equal to his or her expected productivity, conditional upon all available information, and income-maximizing workers who take mobility decisions based on their expected wage schedules. Before we describe the agent's objective functions and determine the equilibrium, it is essential to precise the informational context in which firms make their wage decisions.

Employees are assumed to work for two periods $(t=1,2)$ and maximize expected compensation over their working lives. At the beginning of each period $t$, a worker receives exactly one job offer. The true productivity of an employee in the job offered at period $t, \mu_{t i}$, is a random variable whose distribution is known and identical for men and women: $\mu_{t i} \sim \mathcal{N}\left(\bar{\mu}_{i}, \sigma_{\mu i}^{2}\right)$.

Individuals' productivity depends on the quality of their job match. Moreover, for each individual, 
the true quality of the new job offers received in the two periods, $\mu_{1 i}$ and $\mu_{2 i}$, are independent draws from the underlying match productivity distribution. This latter assumption, standard in Jovanovic (1979) ensures that employees' history is irrelevant to the evaluation of his/her productivity in any newly formed match.

The quality of the match is vulnerable to informational imperfections on both sides of the market. Productivity is ex ante unknown in any potential, but untested, match. Before the match actually occurs, employers and employees alike do not know precisely what the exact productivity will be. It can only be ascertained by observing employee $i$ in the job offered at $t$. More precisely, during the first period all workers will be employed in the job they were offered at the beginning of the period. Let the observed productivity of worker $i$ be given by:

$$
s_{1 i}^{j}=\mu_{1 i}+\varepsilon_{1 i}^{j}, \quad \text { where } \varepsilon_{1 i}^{j} \sim \mathcal{N}\left(0, \sigma_{\varepsilon^{j}}^{2}\right), \quad j \in\{f, m\},
$$

and where superscripts $f$ and $m$ stand for female and male workers, respectively. We assume that $\mu_{1 i}$ and $\varepsilon_{1 i}$ are not correlated. At the start of the second period, the worker must decide whether to stay on the job or move to a new job. If the new offer is accepted, both parties will observe the productivity in the new match with error, as in the first job, i.e.

$$
s_{2 i}^{j}=\mu_{2 i}+\varepsilon_{2 i}^{j}, \quad \text { where } \varepsilon_{2 i}^{j} \sim \mathcal{N}\left(0, \sigma_{\varepsilon^{j}}^{2}\right), \quad j \in\{f, m\} .
$$

If the worker stays in the first-period job, his/her true productivity remains $\mu_{1 i}$, since our model assumes away investment in human capital. On the other hand, the two parties will better assess the true productivity, $\mu_{1 i}$. For stayers we may write observed second-period productivity as:

$$
s^{\prime j}{ }_{1 i}=\mu_{1 i}+v_{i}^{j}, \quad \text { where } v_{i}^{j} \sim \mathcal{N}\left(0, \sigma_{v^{j}}^{2}\right) \text { and } \sigma_{v^{j}}^{2}<\sigma_{\varepsilon^{j}}^{2}, \quad j \in\{f, m\} \text {. }
$$


As in Phelps (1972), gender differences occur essentially through the quality of the productivity signal, i.e. $\sigma_{\varepsilon^{f}}^{2}>\sigma_{\varepsilon^{m}}^{2}$. We further assume that a gap remains irrespective of tenure. This assumption departs from Oettinger (1996) who assumed that the noise/signal ratio vanished after the first period. In fact we assume this to be the case for men, but not for women, i.e. $0=\sigma_{v^{m}}^{2}<\sigma_{v^{f}}^{2}$.

The gender difference in the individual productivity uncertainty has often been justified on cultural grounds [Cornell and Welch (1996); Lazear (1999)]. For example, Henley (1977) and Lang (1986) stress that men and women differ in their communication style and therefore the evaluation process is subject to greater "error" if the candidate is a woman, given that employers and managers are disproportionately men. In the same spirit, Montgomery (1991) shows formally that information about the least represented group in the top-level jobs is usually of lower quality. Recently, Altonji (2005) has argued that unemployment is likely to interact with early statistical discrimination to deter employers' learning. To the extent women typically suffer from higher unemployment then men, they may be less able to convey their true productivity. For all these reasons it seems legitimate to assume that gender differences in the measurement of individual productivity arises not only at the time of hire, but also during employment.

Formally we assume that firms are competitive and risk-neutral, negotiating employee compensation on an individual basis. Employers will offer wages equal to individual expected productivity due to the binding zero expected profits in both periods. In the first period, wage profiles can thus be written as:

$$
w_{1 i}^{j}=\mathbb{E}\left(\mu_{1 i} \mid s_{1 i}^{j}\right), \quad j \in\{f, m\} .
$$

Likewise, second-period wage contracts are determined by individuals' productivity signal, i.e. $s_{1 i}^{\prime j}$ if individual $i$ remains on the job, and $s_{2 i}^{j}$ otherwise. We thus have $w_{2 i}^{j}=\mathbb{E}\left(\mu_{1 i} \mid s_{1 i}^{\prime j}\right)$ for "stayers" and $w_{2 i}^{j}=\mathbb{E}\left(\mu_{2 i} \mid s_{2 i}^{j}\right)$ for "movers". A worker will choose to change jobs if, and only if, the expected 
wage in the second-period job offer exceeds the expected wage in the current job, that is if $\hat{\mu}_{2 i}^{j} \equiv$ $\mathbb{E}\left(\mu_{2 i} \mid s_{2 i}^{j}\right)>\tilde{\mu}_{1 i}^{j} \equiv \mathbb{E}\left(\mu_{1 i} \mid s_{1 i}^{\prime j}\right)$. Wages in the second period can thus be written

$$
w_{2 i}^{j}= \begin{cases}\tilde{\mu}_{1 i}^{j}, & \text { if } \quad \tilde{\mu}_{1 i}^{j}=\mathbb{E}\left(\mu_{1 i} \mid s_{1 i}^{j}\right) \geq \hat{\mu}_{2 i}^{j}=\mathbb{E}\left(\mu_{2 i} \mid s_{2 i}^{j}\right) \text { (stayer) }, \\ \hat{\mu}_{2 i}^{j}, & \text { if } \quad \tilde{\mu}_{1 i}^{j}<\hat{\mu}_{2 i}^{j} \text { (mover). }\end{cases}
$$

Note that the productivity of a male stayer will be perfectly observed. His compensation will be $w_{2 i}^{m}=\tilde{\mu}_{1 i}^{m}=\mu_{1 i}$ and the condition to remain on his original job is $\hat{\mu}_{2 i}^{m} \leq \tilde{\mu}_{1 i}$. Naturally these conditions do not apply to female workers. We will now examine the equilibrium solution and analyze how gender wage gaps may arise.

\section{Equilibrium Wage Profiles}

Equilibrium is determined by the optimization behavior of employers and employees. Firms, which are in a competitive environment, maximize profits by proposing wages, which reflect expected productivity conditional on the individual signal and the group membership. Workers take mobility decisions that maximize their expected lifetime earnings. We will characterize wage profiles in the two periods before drawing conclusions about the returns of mobility, tenure, and experience.

\subsection{First-Period Wages}

For the first period, our analytical framework is identical to the initial statistical discrimination model developed by Phelps (1972) and Aigner and Cain (1977). We obtain the standard result according to which wage contracts are a weighted average of mean productivity $(\bar{\mu})$ and of the individual signal, $S_{1 i}^{j}:$

$$
w_{1 i}^{j}=\mathbb{E}\left(\mu_{1 i} \mid s_{1 i}^{j}\right)=\left(1-\rho_{j}^{2}\right) \bar{\mu}+\rho_{j}^{2} s_{1 i}^{j}, \quad j \in\{f, m\},
$$


where $\rho_{j}^{2}=\sigma_{\mu}^{2} /\left(\sigma_{\mu}^{2}+\sigma_{\varepsilon^{j}}^{2}\right)^{2}$

The weight $\rho_{j}^{2}$ can be interpreted as a measure of the quality of the signal. Thus the greater the reliability of the signal, the more employers will individualize wage rates. Clearly, given the assumption that women's signals are less reliable, ${ }^{3}$ employers will discriminate —rationally- between men and women by offering them different wages. When setting the starting wage of women, they will tend to emphasize the average characteristics of the group over individual performance in order to guard against possible measurement errors. Consequently, men and women with the same productivity signals, $s_{1}$, will receive different compensations. Women with a strong initial signal will receive a lower pay than their male counterparts, and conversely for a weak productivity signal. The wage profile offered to women during the first period is thus less steep than that offered to men, and women's compensation is more clustered around mean productivity, $\bar{\mu}$. Men's wages will in fact have a higher variance $\left(\rho_{m}^{2} \sigma_{\mu}^{2}\right)$ than women's $\left(\rho_{f}^{2} \sigma_{\mu}^{2}\right)$. Yet, men and women will receive the same wage rate upon entry into the labor market. Indeed, expected pay in the first period is invariant with respect to the reliability of the signals

$$
\mathbb{E}\left(w_{1 i}^{j}\right)=\bar{\mu}, \quad j \in\{f, m\}, \forall \rho_{j}^{2} .
$$

Thus first period mean wages are equal to mean productivity, which we assume identical across gender.

\subsection{Second-Period Wages}

Second period wage profiles depend on mobility behavior. As shown previously, stayers' wage rates are characterized by $w_{2 i}^{j}=\tilde{\mu}_{1 i}^{j}=\mathbb{E}\left(\mu_{1 i} \mid s_{1 i}^{\prime j}\right)$ and those of the movers by $w_{2 i}^{j}=\hat{\mu}_{2 i}^{j}=\mathbb{E}\left(\mu_{2 i} \mid s_{2 i}^{j}\right)$. A worker continues with the same job only if $\tilde{\mu}_{1 i}^{j} \geq \hat{\mu}_{2 i}^{j}$ and conversely changes jobs if $\tilde{\mu}_{1 i}^{j}<\hat{\mu}_{2 i}^{j}$. Because mobility is endogenous, non-random selection between movers and stayers must be accounted for

\footnotetext{
${ }^{2}$ To show this, observe that $\mu_{1 i}$ and $s_{1 i}^{j}$ are normal bivariates with correlation coefficient $\rho_{j}^{2}=$ $\sigma_{\mu}^{2} /\left(\sigma_{\mu}^{2}+\sigma_{\varepsilon^{j}}^{2}\right)$. The result follows from computing the conditional expectation.

3 The assumption $\sigma_{\varepsilon^{m}}^{2}<\sigma_{\varepsilon^{f}}^{2}$ implies $\rho_{f}^{2}<\rho_{m}^{2}$.
} 
when characterizing mean compensation. Thus,

- the average second-period wage is given by:

$$
\mathbb{E}\left[\tilde{\mu}_{1 i}^{j} \mid \tilde{\mu}_{1 i}^{j}-\hat{\mu}_{2 i}^{j} \geq 0\right]=\bar{\mu}+\frac{\delta_{j}^{2}}{\sqrt{\delta_{j}^{2}+\rho_{j}^{2}}}\left(\frac{2 \sigma_{\mu}^{2}}{\pi}\right)^{1 / 2}, \quad j \in\{f, m\}
$$

for stayers.

- and

$$
\mathbb{E}\left[\hat{\mu}_{2 i}^{j} \mid \hat{\mu}_{2 i}^{j}-\tilde{\mu}_{1 i}^{j}>0\right]=\bar{\mu}+\frac{\rho_{j}^{2}}{\sqrt{\delta_{j}^{2}+\rho_{j}^{2}}}\left(\frac{2 \sigma_{\mu}^{2}}{\pi}\right)^{1 / 2}, j \in\{f, m\}
$$

for movers,

where $\delta_{j}^{2}=\sigma_{\mu}^{2} /\left(\sigma_{\mu}^{2}+\sigma_{v^{j}}^{2}\right)$. For stayers, $\delta_{j}^{2}$ is a measure of the quality of the signal similar to $\rho_{j}^{2}$ in the first period. ${ }^{4}$ Moreover, since the productivity revelation mechanism is perfect for men $\left(\sigma_{v^{m}}^{2}=0\right)$ but imperfect for women $\left(\sigma_{v^{f}}^{2}>0\right)$, we have $1=\delta_{m}^{2}>\delta_{f}^{2}$. Note that the mean conditional wage rate in the second period is equal to the worker's mean productivity $(\bar{\mu})$, adjusted for the quality of the signal. The expected wage of a mover is lower than that of a stayer $\left(\rho_{j}^{2}<\delta_{j}^{2}\right.$ because $\left.\sigma_{v}^{2}<\sigma_{\varepsilon}^{2}\right)$.

Our model generates positive returns to work experience and tenure. At the beginning of the second period, a mover has one period of experience as an asset, but no tenure, whereas a stayer has both one period of experience and one period of tenure. Thus movers' mean wage differential between the first and the second period characterizes the average return to experience, while the average return to tenure is given by the second-period mean wage differential between stayers and movers. Average returns to experience and tenure are thus given respectively by:

$$
\frac{\rho_{j}^{2}}{\sqrt{\delta_{j}^{2}+\rho_{j}^{2}}}\left(\frac{2 \sigma_{\mu}^{2}}{\pi}\right)^{1 / 2} \text { and } \frac{\delta_{j}^{2}-\rho_{j}^{2}}{\sqrt{\delta_{j}^{2}+\rho_{j}^{2}}}\left(\frac{2 \sigma_{\mu}^{2}}{\pi}\right)^{1 / 2} \text {. }
$$

\footnotetext{
${ }^{4}$ Their wage profile is $w_{2 i}^{j}=\left(1-\delta_{j}^{2}\right) \bar{\mu}+\delta_{j}^{2} s_{1 i}^{\prime j}$
} 
The positive return to tenure captures the fact that the signal is less noisy in the second period. The unconditional second-period mean wage of group $j$ can be derived from equations (8) and (9):

$$
\begin{aligned}
\mathbb{E}\left(w_{2 i}^{j}\right)= & \operatorname{Pr}\left(\tilde{\mu}_{1 i}^{j} \geq \hat{\mu}_{2 i}^{j}\right) \mathbb{E}\left[\tilde{\mu}_{1 i}^{j} \mid \tilde{\mu}_{1 i}^{j}-\hat{\mu}_{2 i}^{j} \geq 0\right] \\
& +\operatorname{Pr}\left(\hat{\mu}_{2 i}^{j}>\tilde{\mu}_{1 i}^{j}\right) \mathbb{E}\left[\hat{\mu}_{2 i}^{j} \mid \hat{\mu}_{2 i}^{j}-\tilde{\mu}_{1 i}^{j}<0\right] \\
= & \bar{\mu}+\left[\frac{\left(\delta_{j}^{2}+\rho_{j}^{2}\right) \sigma_{\mu}^{2}}{2 \pi}\right]^{1 / 2}, \quad j \in\{f, m\} .
\end{aligned}
$$

Thus on average workers earn more in the second period because they self-select into the best possible match. Unlike first-period wage rate, second-period wages increase with the reliability of the signals, $\delta_{j}^{2}$ and $\rho_{j}^{2}$. The better they are, the more profitable the selection process is likely to be on average. Indeed, mistakes such as changing jobs that prove to be a worse match, or foregoing a job change that would have been profitable can be better avoided when productivity signals are more precise.

In this context, male workers should benefit more from mobility. In the second period they should on average receive higher wages than their female co-workers. Our model thus predicts that even if there is no gender wage gap at entry into the labor market, it will appear as careers unfold.

\subsection{Wages and Mobility}

We now consider between-period wage changes. The expected wage change for stayers is given by

$\mathbb{E}\left[\tilde{\mu}_{1 i}^{j}-\hat{\mu}_{1 i}^{j} \mid \tilde{\mu}_{1 i}^{j}-\hat{\mu}_{2 i}^{j} \geq 0\right]$ while that of movers is given by $\mathbb{E}\left[\hat{\mu}_{2 i}^{j}-\hat{\mu}_{1 i}^{j} \mid \hat{\mu}_{2 i}^{j}-\tilde{\mu}_{1 i}^{j}>0\right]$. It can easily 
be shown that

$$
\begin{aligned}
& \mathbb{E}\left[\tilde{\mu}_{1 i}^{j}-\hat{\mu}_{1 i}^{j} \mid \tilde{\mu}_{1 i}^{j}-\hat{\mu}_{2 i}^{j} \geq 0\right]=\frac{\delta_{j}^{2}\left(1-\rho_{j}^{2}\right)}{\sqrt{\delta_{j}^{2}+\rho_{j}^{2}}}\left(\frac{2 \sigma_{\mu}^{2}}{\pi}\right)^{1 / 2}, \\
& \mathbb{E}\left[\hat{\mu}_{2 i}^{j}-\hat{\mu}_{1 i}^{j} \mid \hat{\mu}_{2 i}^{j}-\tilde{\mu}_{1 i}^{j}>0\right]=\frac{\rho_{j}^{2}\left(1+\delta_{j}^{2}\right)}{\sqrt{\delta_{j}^{2}+\rho_{j}^{2}}}\left(\frac{2 \sigma_{\mu}^{2}}{\pi}\right)^{1 / 2} .
\end{aligned}
$$

From equations (11) and (12) it is clear that the expected wage change is positive for both stayers and movers. This result is not surprising since mobility is endogenous. If $\sigma_{\varepsilon}^{2}<\sigma_{\mu}^{2}-$ a reasonable assumption - movers will clearly experience greater wage increases than stayers on average. Indeed wage changes for stayers solely reflect corrections to productivity measurement errors. Conversely, wage changes are essentially attributable to productivity changes in the case of movers.

In summary, our model yields many unambiguous theoretical predictions that can be empirically tested. For both sexes we find that:

1. wage profiles are increasing, on average;

2. experience and tenure show positive returns;

3. movers' mean wage is lower than that of stayers. But

4. their wage growth is greater (assuming that $\sigma_{\varepsilon}^{2}<\sigma_{\mu}^{2}$ ).

As for the male-female wage gap, several results emerge:

1. for identical productivity signals, employers offer compensations that differ across gender;

2. upon entry into the labor market, men and women earn the same wage on average;

3. however, a gender wage gap emerges in the initial years of their working lives.

Some of these predictions are similar to those derived by Oettinger (1996). In fact, the equilibrium described by Oettinger (1996) is a special case of our model in which $\delta_{j}^{2}=1, \forall j$. However, this 
assumption is not innocuous since the productivity revelation mechanism plays an important role in the determination of the second period wage rate. Moreover, our generalization complicates the analysis with respect to differences in the return to mobility and tenure, and changes a number of conclusions. For instance, unlike Oettinger (1996), we cannot assert that women should always have higher returns to tenure than men because the reliability of the initial signals $\left(\rho_{j}^{2}\right)$ and the precision of the revelation mechanism $\left(\delta_{j}^{2}\right)$ act in opposite directions. Likewise, the impact of $\delta_{j}^{2}$ on movers' mean wage increase is ambiguous.

\subsection{Male-Female Gap in the Return to Mobility}

The analysis of gender differences in terms of return to job mobility and tenure is slightly more complex. However, we will show that the sign of these differences not only depends on the male-female gap in the reliability of the initial signals, but also on the magnitude of the variances of the shocks $\left(\sigma_{\varepsilon^{f}}^{2}, \sigma_{v^{f}}^{2}\right)$ relative to the variance of the productivity $\left(\sigma_{\mu}^{2}\right)$.

To ease the derivation of the results let $k \in] 0,1]$ be such that $\sigma_{\varepsilon^{m}}^{2}=k \sigma_{\varepsilon^{f}}^{2}, \alpha=\frac{\sigma_{\varepsilon^{f}}^{2}}{\sigma_{\mu}^{2}}$, and $\beta=\frac{\sigma_{v f}^{2}}{\sigma_{\mu}^{2}}$. We can rewrite the conditions pertaining to the gender differences in job mobility and tenure in terms of $k, \alpha$ and $\beta$. Thus for the average wage of male stayers to be higher to that of female stayers, it is necessary and sufficient according to equation (8) that: ${ }^{5}$

$$
\frac{1}{\sqrt{1+\rho_{m}^{2}}} \geq \frac{\delta_{f}^{2}}{\sqrt{\delta_{f}^{2}+\rho_{f}^{2}}}, \text { or equivalently that } k \geq k_{A}=\frac{\alpha-\beta(3+\alpha+\beta)}{\alpha[1+\beta(3+\alpha+\beta)]}
$$

By the same reasoning, we can derive the following predictions based on equations (8),(9),(11) and

\footnotetext{
${ }^{5}$ Recall that Oettinger (1996)'s model implicitly assumes that: $\sigma_{v^{f}}^{2}=0$ and thus that $\beta=0$ in our framework. His model thus boils down to assuming that $k=1$, i.e. that women's productivity signal is no more noisy than men's signal. Consequently his model precludes male stayers to have a higher mean average wage.
} 
$(12):^{6}$

1. Among the stayers, men's average wage will be higher than women's if $k_{A} \leq k \leq 1$;

2. Among the movers, men's average wage will be higher than women's if $0 \leq k \leq k_{B}$;

3. For male stayers to experience greater wage growth, it must be the case that $k_{c} \leq k \leq 1$;

4. The condition for the male movers' wage growth to exceed that of female movers always obtains;

5. Men's return to tenure will be higher than women's if $k_{E} \leq k \leq 1$.

Ranking these various threshold values of $k$ would allow us to characterize a limited number of baseline cases. The complexity of $k_{A}, k_{B}, k_{C}$, and $k_{E}$ is such that we must turn to numerical simulation. However, if we make the reasonable assumption that the residual variances $\left(\sigma_{\varepsilon^{f}}^{2}, \sigma_{v^{f}}^{2}\right)$ are much smaller than the variance of productivity $\left(\sigma_{\mu}^{2}\right)$, then $\alpha$ will be comprised in the interval $[0,1]$, and $\beta$ in $[0, \alpha]$ due to the manner in which productivity gets less noisy with job tenure ${ }^{7}$. It can be shown that $\left(k_{A}-k_{E}\right),\left(k_{E}-k_{C}\right),\left(k_{E}-k_{B}\right)$ are always negative irrespective of $\alpha$ and $\beta$, while $\left(k_{B}-k_{C}\right)$ can be both positive or negative. Consequently only six baseline cases need be examined. Our model's predictions are summarized in Table 1.

Contrary to Oettinger (1996), our results depend on the discrepancy in the reliability of men's and women's signals. In Oettinger (1996), productivity revelation is perfect, i.e. $\sigma_{v^{f}}^{2}=0$, implying $\beta=0$. This assumption has important repercussions for the threshold values. In fact, for $\beta=0$ we

${ }^{6}$ The expressions for $k_{B}, k_{C}$, and $k_{E}$ are respectively:

$$
\begin{aligned}
& k_{B}=\frac{-3(1+\beta)+\sqrt{9(1+\beta)^{2}+4(1+\alpha)(1+\beta)(2+\alpha+\beta)-8(1+\beta)^{2}}}{2 \alpha(1+\beta)}, \\
& k_{C}=\frac{3 \alpha+\sqrt{9 \alpha^{2}+8\left[(1+\alpha)(1+\beta)(2+\alpha+\beta)-\alpha^{2}\right]}}{2\left[(1+\alpha)(1+\beta)(2+\alpha+\beta)-\alpha^{2}\right]} \\
& k_{E}=\frac{(\alpha-\beta)\left[3 \alpha-3 \beta+\sqrt{9(\alpha-\beta)^{2}+8\left[(1+\alpha)(1+\beta)(2+\alpha+\beta)-(\alpha-\beta)^{2}\right]}\right.}{2 \alpha\left[(1+\alpha)(1+\beta)(2+\alpha+\beta)-(\alpha-\beta)^{2}\right]} .
\end{aligned}
$$

The derivation of $k_{B}, k_{C}$ and $k_{E}$ is available from the authors.

${ }^{7} \sigma_{\varepsilon^{f}}^{2} \geq \sigma_{v}^{2}$ implies that $\beta \leq \alpha$. 
Table 1: Male-female differences in the return to job mobility and tenure

\begin{tabular}{|c|c|c|c|c|c|c|}
\hline & $\begin{array}{c}\text { Case } 1 \\
0 \leq k \leq k_{A}\end{array}$ & $\begin{array}{c}\text { Case } 2 \\
k_{A} \leq k \leq k_{E}\end{array}$ & $\begin{array}{c}\text { Case } 3 \\
k_{E} \leq k \leq k_{B}\end{array}$ & $\begin{array}{c}\text { Case } 4 \\
k_{B} \leq k \leq k_{C}\end{array}$ & $\begin{array}{c}\text { Case } 5 \\
k_{C} \leq k \leq k_{B}\end{array}$ & $\begin{array}{c}\text { Case } 6 \\
k_{C} \leq k \leq 1\end{array}$ \\
\hline $\begin{array}{c}\text { Mean Wages } \\
\text { of stayers }\end{array}$ & $\begin{array}{c}\text { in favor of } \\
\text { women }\end{array}$ & $\begin{array}{c}\text { in favor of } \\
\text { men }\end{array}$ & $\begin{array}{c}\text { in favor of } \\
\text { men }\end{array}$ & $\begin{array}{c}\text { in favor of } \\
\text { men }\end{array}$ & $\begin{array}{c}\text { in favor of } \\
\text { men }\end{array}$ & $\begin{array}{c}\text { in favor of } \\
\text { men }\end{array}$ \\
\hline $\begin{array}{c}\text { Mean Wages } \\
\text { of movers }\end{array}$ & $\begin{array}{c}\text { in favor of } \\
\text { men }\end{array}$ & $\begin{array}{c}\text { in favor of } \\
\text { men }\end{array}$ & $\begin{array}{c}\text { in favor of } \\
\text { men }\end{array}$ & $\begin{array}{c}\text { in favor of } \\
\text { women }\end{array}$ & $\begin{array}{c}\text { in favor of } \\
\text { men }\end{array}$ & $\begin{array}{c}\text { in favor of } \\
\text { women }\end{array}$ \\
\hline $\begin{array}{c}\text { Return to } \\
\text { Tenure }\end{array}$ & $\begin{array}{c}\text { in favor of } \\
\text { women }\end{array}$ & $\begin{array}{c}\text { in favor of } \\
\text { women }\end{array}$ & $\begin{array}{c}\text { in favor of } \\
\text { men }\end{array}$ & $\begin{array}{c}\text { in favor of } \\
\text { men }\end{array}$ & $\begin{array}{c}\text { in favor of } \\
\text { men }\end{array}$ & $\begin{array}{c}\text { in favor of } \\
\text { men }\end{array}$ \\
\hline $\begin{array}{l}\text { Mean-Wage } \\
\text { Gain, stayers }\end{array}$ & $\begin{array}{c}\text { in favor of } \\
\text { women }\end{array}$ & $\begin{array}{c}\text { in favor of } \\
\text { women }\end{array}$ & $\begin{array}{c}\text { in favor of } \\
\text { women }\end{array}$ & $\begin{array}{c}\text { in favor of } \\
\text { women }\end{array}$ & $\begin{array}{c}\text { in favor of } \\
\text { men }\end{array}$ & $\begin{array}{c}\text { in favor of } \\
\text { men }\end{array}$ \\
\hline $\begin{array}{l}\text { Mean-Wage } \\
\text { Gain, movers }\end{array}$ & $\begin{array}{c}\text { in favor of } \\
\text { men }\end{array}$ & $\begin{array}{c}\text { in favor of } \\
\text { men }\end{array}$ & $\begin{array}{c}\text { in favor of } \\
\text { men }\end{array}$ & $\begin{array}{c}\text { in favor of } \\
\text { men }\end{array}$ & $\begin{array}{c}\text { in favor of } \\
\text { men }\end{array}$ & $\begin{array}{c}\text { in favor of } \\
\text { men }\end{array}$ \\
\hline
\end{tabular}

find that $k_{A}=k_{B}=k_{C}=k_{E}=1$. Consequently, whatever the value of $\left.\left.k \in\right] 0,1\right]$, we find that $k \leq k_{A}$. Furthermore, we can show that the predictions in Oettinger (1996) correspond to the first column of Table 1. Recall that his model yielded a positive gap in men's returns to mobility, and that tenure was more highly valued by women.

An empirical study based on wage equations will allow us to distinguish between the differences in the returns of job mobility and tenure for men and women. We can then establish whether the data are consistent with any of our theoretical predictions.

\section{Data and Empirical Analysis}

\subsection{The Sample}

In this section, we test the unambiguous predictions of our statistical discrimination model and focus on the theoretical ambiguities surrounding differences in the returns to job mobility and tenure. In particular, the analysis will attempt to shed some light on how the wage gap evolves in the earliest stages of work and on the importance of job mobility in the process.

To test the theory, we use data drawn from the 1979 cohort of the National Longitudinal Survey of Youth (NLSY). This survey follows a cohort representative of young Americans aged 14 to 21 in 
1979. It provides extensive longitudinal data on educational achievements, wages, and work experience from 1979 to 2008. In this study we focus on white individuals from the cross-sectional sample of the NLSY and exclude the supplemental sample of economically disadvantaged whites.

Our aim is to follow the evolution of wages at the beginning of young adults' career. Since our model does not include labor supply, we follow Oettinger (1996) by focusing on an individual's first observable transition from weak to strong labor force attachment. Respondents are considered to be strongly attached to the labor force during a specific survey year if they worked at least half of all weeks since the last survey, ${ }^{8}$ and if they worked at least an average of 30 hours during each of those weeks. The onset of a respondent's career is the first of three consecutive survey years of strong labor force attachment that follow one year of weak labor force attachment. ${ }^{9}$ We then follow each respondent's wage evolution for up to ten years following that first transition into strong labor force attachment, keeping in our sample only wage observations preceded by a year of strong labor force attachment. ${ }^{10}$ Consistent with our requirement of measuring wages every year, we do not consider NLSY data collected after 1994 since surveys were then conducted every two years.

Wage is measured at the end of each year of strong labor force attachment. ${ }^{11}$ We use hourly wage for a job held at the time of the survey. If a respondent holds more than one job at the time of the survey, we use the hourly wage for the job at which the respondent worked most hours. Wages

\footnotetext{
${ }^{8}$ The number of weeks between each survey is not necessarily 52 weeks, so we restrict our sample to respondents-survey years with 45 to 59 weeks since the last survey.

${ }^{9}$ Respondents who are observed to have strong labor force attachment in survey year 1979 are excluded from the sample.

${ }^{10}$ We also experimented with a sample that excluded individuals who experienced one year of weak labor force attachment after their first three years of strong attachment. This results in a much smaller sample, larger standard errors, but qualitatively similar results.

${ }^{11}$ Ideally we would have identified the respondent's "first job" and the wage associated with that job. However, the NLSY provides no question or variable referring to an individual's first job. Many respondents hold jobs while enrolled in school, but these may not be jobs associated with their eventual careers. Other respondents may be out of school and hold jobs, but are not strongly attached to the labor market. This makes it hard to identify the first job associated with their eventual career and we opted instead to look at hourly wage for jobs held at the end of each year of strong labor force attachment.
} 
are measured in 2004 dollars and included in the sample if they are greater than $\$ 1$ and less than $\$ 60$.

Educational achievements is measured using years of completed schooling. We focus on individuals who have completed at least 13 years of education at the end of their career's first year. The rationale is that our model assumes male and female workers to have the same level of commitment to the labor market. This assumption is more likely to hold in a sample of individuals who have invested in post-secondary education. The sample of individuals with no post-secondary education may display greater variation in their attachment to the labor force, and the mechanisms behind this variation likely differ between men and women given that women's educational and labor supply choices are affected by their fertility decisions. Although fertility decisions also affect female workers with post-secondary decisions, it can be argued that higher household earnings and stronger investments in human capital of more educated couples reduce the scope for fertility decisions affecting female labor supply.

The model has strong predictions about the impact of work experience, job tenure, and job changes on wages. Work experience is a variable that counts the number of year of strong labor force attachment since the first transition into strong attachment. Job tenure measures the number of consecutive weeks at a given job. To identify a job change, we compare the week when the currently held job started, to the week when the previous survey interview took place. If the currently held job started after the previous survey, a respondent is considered to have changed jobs.

Our model makes it clear that job changes are triggered if workers receive large shocks to their productivity signals, or if they get good productivity draws with another employer. These productivity draws and signal shocks are observed by the worker, but not by the econometrician, and are incorporated in the error term of our wage equation. This error term is therefore correlated with any explanatory variable describing job changes or job tenure. These variables are instrumented using lagged job changes, lagged job tenure, and lagged annual hours of work. We used lagged values because our model assumes that productivity draws and signal shocks are not correlated across pe- 
riods. The first two instruments should be correlated with current job changes and tenure through other factors not correlated with the worker's own wage, such as shocks to household structure, or a stronger preference for job mobility. Lagged hours of work should identify job changes triggered by adjustment on the labor supply margin, rather than wages.

To proxy ability, our regressions include the score percentile of the Armed Force Qualification Test (AFQT). ${ }^{12}$ This variable is meant to capture the fact that employers may partly observe the worker's ability and adjust compensation accordingly. We also include a dummy variable that controls for whether the job is covered by a collective bargaining agreement, acknowledging the fact that other external mechanisms may determine wages. In the same vein we include dummy variables for occupation and industry to reflect how work in these different professions and firms are rewarded in the product market. ${ }^{13}$

Our sample consists of 505 women, and 474 men with at least some college whom we observe a year following their first transition into strong labor force attachment. Table 2 provides summary statistics on some of the variables used in the empirical analysis. It shows the distribution of the year during which workers made their transition into strong labor force attachment. For $90 \%$ of the sample, this first transition took place in years 1980 to 1988. On average these workers made their first transition into the labor force at the age of 23 , which is consistent with the fact that they completed on average 15 years of education. Almost $57 \%$ of the sample had completed 4 years or

${ }^{12}$ The AFQT score aggregates results for tests on word knowledge, paragraph comprehension, mathematics knowledge, and arithmetic reasoning. The AFQT is a subset of the Armed Services Vocational Aptitude Battery administered to NLSY respondents in 1980. At that time, age varied from 15 to 22 among respondents, it is known that performance on the AFQT test is positively correlated with age at time of the test. We therefore use AFQT test scores adjusted for age at the time of the test.

${ }^{13}$ Previous research has shown that occupations and industries are coded with error in the NLSY. We ignore any industry change that is not associated with a job change. Occupation is allowed to change without any job change. However, we ignore any occupation "cycling" within the same job: if an occupation change is observed within the same job, it is ignored if the occupation at this same job is observed to have changed again at the next survey interview. 
more of college by the time of their first transition.

At the end of the first year of strong labor force attachment, women and men earn an average hourly wage rate of $\$ 12$ and $\$ 13$, respectively. Two years later, their respective average hourly wage rate has increased to $\$ 14$ and $\$ 16$. As many as $72 \%$ of men and $67 \%$ for women change job at the end of their first year of employment. But mobility decreases as their careers unfold, down to about $30 \%$ for men and women by the end of the third year. By that time, $14 \%$ of male and female workers are covered by a collective agreement.

Labor supply during that first year of strong labor force attachment is quite similar for men and women. Indeed, men worked on average 1,950 hours over 46 weeks, while women worked 1,800 hours over 45 weeks. Two years on, labor supply is slightly higher for workers of both genders.

After their first year of strong attachment, the majority of women are either professionals (36\%) or clerical workers (30\%). Two years on, both occupations are still the most prevalent at $43 \%$ and $26 \%$, respectively. Early on, men are more likely to work as professionals (37\%) or service workers $(11 \%)$ and managers (11\%). Two years on, they are mostly professionals (38\%), managers (13\%), and sales workers (11\%).

The two most prevalent industries for women are professional and related services (39\%) and in wholesale or retail trade $(21 \%)$. Two years on, these two industries represent respectively $38 \%$ and $19 \%$ of all jobs. Male workers work mostly in wholesale and retail trade, manufacturing and professional services industry (20\% each). Two years on, the professional service industry represents $19 \%$ while manufacturing's share is higher $(24 \%)$.

\subsection{Estimation Results}

We test our model's predictions using reduced-form log-wage regressions. Our sample includes all individuals that have completed at least three years of strong labor force attachment following one 
year of weak labor attachment. We follow their hourly wage over those first three years of strong labor force attachment, but we also add to our sample hourly wages observed after a year of strong labor force attachment over the next seven years. Our sample of individual-wage observations contains real wages (in 2004 dollars) from 1980 to 1994.

\subsubsection{The Gender Wage Gap}

The main results concerning the gender wage gap are presented in Table 3. All results presented in Table 3 are OLS estimates. The first column contains results for a model where we only control for gender, age, years of education, AFQT, and a dummy variable for collective bargaining. ${ }^{14}$ This column shows that female wages are about $8.3 \%$ lower than that of men, and that this gender wage gap is statistically significant. Since there is no control for work experience, age is associated with strong wage growth. As expected, years of education, AFQT and collective bargaining are associated with higher wages.

Models 2 to 4 gradually add more variables to the model and allows us to study how that affects the gender wage gap. In Model 2 we add a variable for work experience, which is measured by years of strong labor force attachment. As expected years of experience are associated with strong wage growth: $4.2 \%$ for each year of strong labor force attachment. Even after adding years of experience, we still find that women earn on average $8.3 \%$ less per hour of work.

In Model 3 we add an interaction term between work experience and the gender dummy variable. Remember that the model predicts that male and female workers have the same starting wage, and that the lower quality of productivity signaling for women implies that female wage should grow at a slower rate. Consistent with this, we find that the gender wage gap is reduced to less than $2 \%$ and is not statistically significant. Moreover, the parameter on the interaction between gender and

\footnotetext{
${ }^{14}$ Although we do not present the results here, we also include in all models a set of dummy variables to account for occupation and industry.
} 
work experience also reveals that wage growth is weaker for women: one year of strong labor force attachment leads to a 3.4\% wage growth, compared to $4.9 \%$ for men, and this difference is statistically significant. ${ }^{15}$

Other mechanisms could generate weaker wage growth for women. If most women in our sample expect to have children and therefore make fewer on-the-job human capital investments, we should observe weaker wage growth for women. In Model 4, we include variables that control for marital status and the presence of children at home. The dummy variable for being married and its interaction with gender indicate that being married is associated with higher wages, but much less so for women. The parameter on a dummy variable for the presence of at least one child in the household indicates that having children is associated with lower wages. ${ }^{16}$ Including these household related variables show that the gap in wage growth from strong labor force attachment decreases, but remains statistically significant at $1 \%$, compared to $1.5 \%$ in Model 3. It suggests that part of the weaker female wage growth may be explained by different on-the-job human capital investments.

\subsubsection{Job Changes and Job Tenure}

Our model also has predictions regarding the comparative wages of workers who keep the same job (stayers) and those who change job (movers). We test these predictions in Table 4. The first column reports the results of Model 3 from Table 3 where it was found that controlling for years of experience resulted in a statistically insignificant gender wage gap. Models 5 to 7 are 2SLS estimates. As

\footnotetext{
${ }^{15}$ These results are consistent with Loprest (1992) who uses the NLSY79 to find that women have weaker wage growth than men. Although she also considers a sample of workers with consecutive years of strong labor force attachment, her sample contains workers who did not go to college. If we consider workers of all educational levels we still find that returns to experience are lower for women, however this difference is not statistically different once marital and parental status are accounted for, variables that are not considered in Loprest (1992).

${ }^{16}$ We also tried adding an interaction term between gender and the child dummy variable to Model 4. We found both the child dummy variable and its interaction with gender to be negative, but not statistically significant.
} 
explained in Section 4.1, job changes, and by construction job tenure, are endogenous variables. We instrument them with their own lagged values, as well as lagged hours of work.

Model 5 of Table 4 adds a dummy variable indicating whether the individual changed job since the last survey interview. We also include an interaction between gender and job change. Our results show that movers have on average lower wages, as predicted by our model (see Section 3.3). Moreover, the mover wage penalty is greater for women, indicating that the mean wage of movers is greater for men. Note also that the coefficient on gender is now positive and statistically significant, indicating that, among stayers, women have a higher mean wage. Stronger mean wage for women among stayers, and stronger mean wage for men among movers is consistent with Case 1 of Table 1.

The coefficients associated with job changes in Model 5 of Table 4 are quite large. It is very likely that these job changes are not all voluntary. Individuals who, in the high unemployment rates of the early 1980s, suffered from layoffs, but remained in strong labor force attachment (a requirement of our sample selection), may have done so by taking on a job (or multiple jobs) that offered lower wages. Our results suggest that this might have been more severe for women. Compounding all of this is the fact that we use lagged job change variables as instruments. These may tend to identify the negative impact of job losses over multiple years on the wages of workers who nevertheless remain in strong labor force attachment. However, it should be kept in mind that these are log hourly wage regressions, so that measured in actual dollars, the impact of job changes represent small amounts. ${ }^{17}$

Model 6 includes a linear and quadratic term in job tenure weeks, as well as interactions between these terms and gender. ${ }^{18}$ Tenure coefficients indicate that wages grow with tenure, as predicted by our model. Moreover, this growth is significantly stronger for women, which is also consistent with

\footnotetext{
${ }^{17}$ For example, the intercept of Model 5 in Table 4 implies a base hourly wage of $\$ 4.58$, relative to an average wage of $\$ 16.68$ in that regression sample. The coefficients for job change variables imply that the base hourly wage of movers is around $\$ 3.52$ for men and $\$ 1.78$ for women.

${ }^{18}$ The quadratic term in tenure is divided by 10,000 for the sake of presentation. This should be kept in mind when interpreting the value of its coefficient.
} 
Case 1 of Table 1 which predicts larger returns to tenure for women. These coefficients on job tenure imply that 52 weeks with the same employer lead to $4.1 \%$ wage growth for men, compared to $7.5 \%$ for women.

Model 6 in Table 4 also suggests that women suffer from a marginally statistically significant wage penalty of approximately $5 \%$. This is probably due to the fact that workers with very low tenure include those who changed jobs. These movers, and especially female movers, suffer from severe wage penalties as shown in Model 5, and the assumed quadratic impact of job tenure is not flexible enough to allow for this nonlinear impact of tenure. The gender dummy variable may therefore be picking up the larger penalty of job changes for women. With Model 7 in Table 4 we study the joint impact of job changes and tenure. We still find that workers suffer from changing jobs, although the effect is not statistically significant for men (this result remains consistent with Case 1 of Table 1 ). Tenure is still associated with statistically significant wage growth, but we find no stronger returns to tenure for women, contrary to Model 6. ${ }^{19}$ Finally, we find that female stayers have higher average wage, which is consistent with Model 5 and Case 1 of Table 1.

\subsubsection{Wage Growth and Job Changes}

A clear prediction of the model from Section 3.3 is that although movers' mean wage is lower than that of stayers, their wage growth is stronger. To test this prediction, as well as predictions about the mean wage gain across genders of stayers and movers (last two rows of Table 1 ), we study wage growth in Table 5. The dependent variable is the difference between the current log hourly wage and the log wage recorded at the previous survey. All regressions presented in Table 5 control for

\footnotetext{
${ }^{19}$ We also experimented with linear as well as quadratic terms in tenure (as in Model 6) but all were imprecisely estimated. We therefore opted for the more parsimonious Model 7 with no quadratic term.
} 
collective bargaining coverage, occupation and industry. ${ }^{20}$ All regressions also control for age, years of schooling, ability as measured by the AFQT score percentile, as well as a dummy variable for gender. Model 8 shows that, consistent with our previous findings in Table 3, women have weaker wage growth, although the coefficient is not precisely estimated. However, once we control for hours of work in Model 9, the impact of gender is marginally statistically significant and in favor of men. Hours of work can be seen as controls for the amount of on-the-job human capital investment, and are associated with statistically significant stronger wage growth. Comparing the gender gap in wage growth from Model 8 to 9 indicates that women can make up for their noisier productivity signals through on-the-job investments.

One clear prediction of Section 3.3 is that movers should experience stronger wage growth. Model 9 tests this prediction by adding a dummy variable indicating whether the worker holds a job he was not holding at the previous interview. As previously explained, this variable is endogenous. Because we are now estimating wage growth equations, where lagged hourly wage are part of the dependent variable, we instrument job change variables with second order lags of job changes and hours worked. The coefficient on job change is positive and statistically significant, which is consistent with the prediction of our model that movers should have stronger wage growth relative to stayers. Model 11 includes an interaction between job change and gender to test among movers and stayers which gender has stronger mean wage gains. The results are inconclusive as the parameter estimate is not statistically different from zero.

\footnotetext{
${ }^{20}$ We include dummy variables for all possible state transitions. For example, collective bargaining includes a dummy variable for individuals who stayed covered by a collective agreement, a dummy variable for individuals who lost their coverage, and a dummy variable for individuals who gained collective bargaining agreement, leaving those who remained uncovered as the base case.
} 


\subsubsection{Implications for Signal Quality and Productivity Revelation Across Genders}

Our empirical results support Case 1 of Table 1 . This has implications for the comparison across genders of signal quality in a new job, and the productivity revelation for workers who do not change job. These matters because they are the source of wage growth and job mobility in our model.

Assuming that productivity revelation is perfect for men, Case 1 entails that signal quality in a new job is good for men. For women signal quality is bad but productivity revelation is good. ${ }^{21}$ This implies that only women with very low productivity or bad post-hiring noise do not keep their current job. This tends to remove the extreme left part of the signal distribution among female stayers, increasing their observed average wage. The average wage of male stayers also increases but to a smaller extent because employers do not revise their expectations about their productivity so much as they do for women. Contrary to women, the majority of male movers are not drawn only from extreme left tail of the signal distribution because of their lower noise/signal ratio. It follows that male workers move only if they get a much better draw (productivity and noise wise) at a new job, implying that among movers, men have the largest average wage, whereas women have a higher average wage then men among stayers. Estimates from Model 5 of Table 4 lend support to these conjectures: women stayers have higher wage (coefficient on dummy for gender is positive and statistically significant) while male movers earn on average more than female stayers (the interaction between gender and job change dummy variables is negative and statistically significant).

Wage gains from staying at the same job depends solely on the improvement in signalling stemming from holding on to a job. The conditions that lead to Case 1 implies that this improvement is stronger for women, with the results that returns to tenure are stronger for women as found in Model 6 of Table 4. This also implies that wage growth among stayers should be stronger for women, but Models 10

\footnotetext{
${ }^{21}$ Remember from section 3.4 that Case 1 implies $k<k_{A}$, where $k$ decreases as the signal quality increases for men, while $k_{A}$ increases as the signal quality for women weakens, and as the revelation mechanism for women improves.
} 
and 11 in Table 5 are inconclusive on this issue. The two models are also inconclusive with regards to the predicted stronger movers wage growth among men. Wage gains for movers depend on the quality of signalling at new jobs but also on the revelation mechanism, which are both stronger for men.

\section{Conclusion}

In this paper we investigate the gender wage gap using a two-period model based on the theories of matching and statistical discrimination. Simply by assuming that women's true productivity is more costly to measure, and that the noisiness of women's signal tapers off less rapidly than men's, it is possible to generate a series of theoretical predictions about wage gaps. These pertain to the relation between wage gaps and mobility, tenure and experience. To our knowledge, only three other papers

[Oettinger (1996); Neumark (1999); Altonji and Pierret (2001)] have empirically tested the validity of the theory of statistical discrimination within a similar framework.

The theoretical predictions are tested using U.S. data from the 1979 cohort of the National Longitudinal Survey of Youth. The data supports most of these predictions. We find that, though men and women with post-secondary education earn identical wages upon entry into the labor market, a substantial gap emerges in men's favor in the next few years. Other clear predictions of the model are supported: work experience and tenure are associated with higher wages. Average wages are higher among workers who do not change job (stayers), while job changers (movers) experience stronger wage growth.

The theoretical model has ambiguous predictions about gender-related mean wage among stayers, mean wage among movers, returns to tenure, mean wage gains among stayers, and mean wage gains of movers. However, the model provides enough structure to limit its predictions to six possible cases, which we present in Table 1. Although our results are inconclusive with regards to mean wages gains, 
we find evidence that supports Case 1 whereby women have stronger mean wages among stayers and stronger returns to tenure, while men have stronger mean wages among movers. Case 1 implies that employers are better at inferring the productivity of new male employees, while finding it much more difficult to do so with female employees. However, Case 1 also implies that employers eventually get a precise estimate of female workers' productivity with tenure. 


\section{References}

Aigner, Denis, and Glen Cain (1977) 'Statistical theories of discrimination in labor market.' Industrial and Labor Relations Review 30(2), 175-187

Altonji, Joseph (2005) 'Employer learning, statistical discrimination and occupational attainment.' American Economic Review 95(2), 112-117

Altonji, Joseph, and Charles Pierret (2001) 'Employer learning and statistical discrimination.' Quaterly Journal of Economics 116(1), 313-350

Altonji, Joseph, and Rebecca Blank (1999) 'Race and gender in the labor market.' In Handbook of Labor Economics, ed. Orley Ashenfelter and David Card, vol. 3C Elsevier Science, North-Holland pp. 3143-3259

Arrow, Kenneth (1973) 'The theory of discrimination.' In Discrimination in Labor Markets, ed. Orley Ashenfelter and Albert Rees Princeton University Press pp. 3-33

Barron, John, Dan Black, and Mark Loewenstein (1993) 'Gender differences in training, capital, and wages.' Journal of Human Resources 28(2), 343-364

Becker, Gary (1957) The Economics of Discrimination, second edition ed. (The University of Chicago Press Economics)

Black, Dan (1995) 'Discrimination in a equilibrium search model.' Journal of Labor Economics 13(2), 309-334

Bowlus, Audra, and Zvi Eckstein (2002) 'Discrimination and skill differences in a equilibrium search model.' International Economic Review 43(4), 1309-1345

Burdett, Kenneth (1978) 'A theory of employee job search and quit rates.' American Economic Review $68(1), 212-220$

Cain, Glen (1986) 'The economic analysis of labor market discrimination : A survey.' In Handbook of Labor Economics, ed. Orley Ashenfelter and Richard Layard, vol. 1 Elsevier Publishing Company pp. 693-785

Coate, Stephen, and Glenn Loury (1993) 'Will affirmative-action policies eliminate negative stereotypes ?' American Economic Review 83(5), 1220-1240

Cornell, Bardford, and Ivo Welch (1996) 'Culture, information, and screening discrimination.' Journal of Political Economy 104(3), 542-571

Del Bono, Emilia, and Daniela Vuri (2011) 'Job mobility and the gender wage gap in Italy.' Labour Economics 18(1), 130-142

Fang, Hanming, and Andrea Moro (2011) 'Theories of statistical discrimination and affirmative action: A survey.' In Handbook of Social Economics, ed. Jess Benhabib, Matthew Jackson, and Alberto Bisin, vol. 1A The Netherlands: North-Holland pp. 133-200

Flabbi, Luca (2010) 'Gender discrimination estimation in a search model with matching and bargaining.' International Economic Review 51(3), 745-783 
Fryer, Roland (2007) 'Belief flipping in a dynamic model of statistical discrimination.' Journal of Public Economics 91, 1151-1166

Havet, Nathalie (2004) 'Ecarts salariaux et disparités professionnelles entre sexes : développements théoriques et validité empirique.' I'Actualité Economique, Revue d'Analyse Economique 80, 3-31

Havet, Nathalie, and Catherine Sofer (2008) 'Why do women's wages increase so slowly throughout their career? A dynamic model of statistical discrimination.' Labour 22(2), 291-314

Henley, Nancy (1977) Body Politics : Power, Sex and Nonverbal Communication (N-J : Prentice-Hall)

Jovanovic, Boyan (1979) 'Job matching and the theory of turnover.' Journal of Political Economy 87(5), 972-980

Lang, Kevin (1986) 'A language theory of discrimination.' Quaterly Journal of Economics 101(2), 363382

Lazear, Edward (1999) 'Culture and language.' Journal of Political Economy 107(6), S46-S126

Lazear, Edward, and Sherwin Rosen (1990) 'Male-female wage differentials in job ladders.' Journal of Labor Economics 8(1), S106-S123

Light, Audrey, and Manuelita Ureta (1992) 'Panel estimates of male and female job turnover behavior: can female nonquitters be identified?' Journal of Labor Economics 10(2), 156-181

Loprest, Pamela (1992) 'Gender differences in wage growth and job mobility.' American Economic Review 82(2), 526-532

Lundberg, Shelly, and Richard Startz (1983) 'Private discrimination and social intervention in competitive labor market.' American Economic Review 73(3), 340-347

Manning, Alan, and Joanna K. Swaffield (2008) 'The gender gap in early-career wage growth.' The Economic Journal 118(530), 983-1024

Montgomery, James D. (1991) 'Social networks and labour market outcomes: Towards an economic analysis.' American Economic Review 81(5), 1408-1418

Moro, Andrea (2003) 'The effect of statistical discrimination on black-white wage differentials: Estimating a model with multiple equilibrium.' International Economic Review 44(2), 467-500

Moro, Andrea, and Peter Norman (2004) 'General equilibrium model of statistical discrimination.' Journal of Economic Theory 114(1), 1-30

Napari, Sami (2009) 'Gender differences in early-career wage growth.' Labour Economics 16, 140-148

Neumark, David (1999) 'Wage differentials by race and sex: The roles of taste discrimination and labor market information.' Industrial Relations 38(3), 414-445

Oettinger, Gerald (1996) 'Statistical discrimination and the early career evolution of the black-white wage gap.' Journal of Labor Economics 14(1), 52-78

Phelps, Edmund (1972) 'The statistical theory of racism and sexism.' American Economic Review 62(4), 659-661 
Rosen, Asa (2003) 'Search, bargaining and employer discrimination.' Journal of Labor Economics 21(4), 807-829

Rothschild, Michael, and Joseph Stiglitz (1982) 'A model of employment outcomes illustrating the effect of the structure of information on the level and distribution of income.' Economics Letters $10,231-236$

Sasaki, Masaru (1999) 'An equilibrium search model with coworker discrimination.' Journal of Labor Economics 17(2), 377-407

Sattinger, Michael (1996) 'Search and discrimination.' Labour Economics 3(2), 143-167

Simpson, Wayne (1990) 'Starting even? job mobility and the wage gap between young single males and females.' Applied Economics 22(6), 723-737

Sulis, Giovanni (2011) 'Gender wage differentials in Italy: A structural estimation approach.' Journal of Population Economics 25(1), 53-87 
Table 2: Descriptive statistics

\begin{tabular}{|c|c|c|}
\hline & Men & Women \\
\hline \multicolumn{3}{|l|}{ Entry Year and Age } \\
\hline Before 1983 & $23.0 \%$ & $26.7 \%$ \\
\hline 1983 & $12.2 \%$ & $14.7 \%$ \\
\hline 1984 & $14.8 \%$ & $16.4 \%$ \\
\hline 1985 & $14.6 \%$ & $15.3 \%$ \\
\hline 1986 & $13.5 \%$ & $10.3 \%$ \\
\hline After 1986 & $21.9 \%$ & $16.6 \%$ \\
\hline Age & 23.2 & 22.8 \\
\hline \multicolumn{3}{|l|}{ Entry Education } \\
\hline Years of Education & 15.4 & 15.2 \\
\hline At Least 16 Years of Education & $56.3 \%$ & $57.2 \%$ \\
\hline \multicolumn{3}{|c|}{ Wage, Job Change, Job Tenure, Collective Bargaining } \\
\hline \multicolumn{3}{|c|}{ After First Year } \\
\hline Hourly Wage (2004 \$) & 12.96 & 11.67 \\
\hline Job Change & $71.5 \%$ & $67.4 \%$ \\
\hline Job Tenure (Weeks) & 52.0 & 53.3 \\
\hline Collective Bargaining & $10.7 \%$ & $11.7 \%$ \\
\hline \multicolumn{3}{|l|}{ After Third Year } \\
\hline Hourly Wage (2004 \$) & 16.32 & 13.81 \\
\hline Changed Job & $29.5 \%$ & $29.6 \%$ \\
\hline Job Tenure (Weeks) & 109.2 & 106.6 \\
\hline Collective Bargaining & $13.6 \%$ & $14.1 \%$ \\
\hline \multicolumn{3}{|l|}{ Labor Supply } \\
\hline \multicolumn{3}{|l|}{ After First Year } \\
\hline Weeks Worked & 45.6 & 45.3 \\
\hline Hours Worked & 1,956 & 1,803 \\
\hline \multicolumn{3}{|l|}{ After Third Year } \\
\hline Weeks Worked & 50.7 & 50.3 \\
\hline Hours Worked & 2,305 & 2,131 \\
\hline
\end{tabular}

Sample includes white men and women who are observed transitioning from one year of weak labor force attachment (LFA) to three consecutive years of strong LFA, and who had completed at least one year of college by the end of their first year of strong LFA. The definition of strong LFA is provided in section 4.1. The entry year is the survey year during which the individual is observed having completed their first year of strong LFA. 
Table 4: Job Changes and Job Tenure

\begin{tabular}{|c|c|c|c|c|}
\hline Variables & Model 3 & Model 5 & Model 6 & Model 7 \\
\hline \multirow[t]{2}{*}{ Intercept } & 1.3911 & 1.5209 & 1.3634 & 1.4430 \\
\hline & $(0.0712)$ & $(0.1310)$ & $(0.0741)$ & $(0.1478)$ \\
\hline \multirow[t]{2}{*}{ Female } & -0.0157 & 0.2934 & -0.0514 & 0.3317 \\
\hline & $(0.0207)$ & $(0.1316)$ & $(0.0292)$ & $(0.1639)$ \\
\hline \multirow[t]{2}{*}{ Experience } & 0.0492 & 0.0441 & 0.0389 & 0.0423 \\
\hline & $(0.0037)$ & $(0.0080)$ & $(0.0044)$ & $(0.0079)$ \\
\hline \multirow[t]{2}{*}{ Experience $\times$ Female } & -0.0153 & -0.0461 & -0.0225 & -0.0479 \\
\hline & $(0.0039)$ & $(0.0135)$ & $(0.0053)$ & $(0.0132)$ \\
\hline \multirow[t]{2}{*}{ Job Change } & & -0.2633 & & -0.1516 \\
\hline & & $(0.1416)$ & & $(0.1765)$ \\
\hline \multirow[t]{2}{*}{ Job Change $\times$ Female } & & -0.6790 & & -0.7715 \\
\hline & & $(0.2880)$ & & $(0.3534)$ \\
\hline \multirow[t]{2}{*}{ Job Tenure } & & & 0.0008 & 0.0002 \\
\hline & & & $(0.0002)$ & $(0.0001)$ \\
\hline$(\text { Job Tenure })^{2}(/ 10,000)$ & & & $\begin{array}{l}-0.0093 \\
(0.0036)\end{array}$ & \\
\hline \multirow[t]{2}{*}{ Job Tenure $\times$ Female } & & & 0.0007 & -0.0001 \\
\hline & & & $(0.0003)$ & $(0.0002)$ \\
\hline \multirow[t]{2}{*}{$(\text { Job Tenure })^{2} \times$ Female $(/ 10,000)$} & & & -0.0089 & \\
\hline & & & $(0.0055)$ & \\
\hline \multirow[t]{2}{*}{ Age } & 0.0153 & 0.0076 & 0.0129 & 0.0071 \\
\hline & $(0.0026)$ & $(0.0035)$ & $(0.0027)$ & $(0.0035)$ \\
\hline \multirow[t]{2}{*}{ Years of Education } & 0.0351 & 0.0464 & 0.0392 & 0.0486 \\
\hline & $(0.0041)$ & $(0.0062)$ & $(0.0042)$ & $(0.0064)$ \\
\hline \multirow[t]{2}{*}{ AFQT Percentile } & 0.0025 & 0.0020 & 0.0023 & 0.0020 \\
\hline & $(0.0003)$ & $(0.0004)$ & $(0.0003)$ & $(0.0004)$ \\
\hline \multirow[t]{2}{*}{ Collective Bargaining } & 0.0794 & 0.0321 & 0.0647 & 0.0294 \\
\hline & $(0.0159)$ & $(0.0212)$ & $(0.0164)$ & $(0.0212)$ \\
\hline Sample Size & 5,705 & 5,217 & 5,184 & 5,184 \\
\hline \multicolumn{5}{|c|}{$\begin{array}{l}\text { Standard errors in parentheses. Dependent variable is log hourly wage. Sample } \\
\text { includes white men and women who are observed transitioning from one year } \\
\text { of weak labor force attachment (LFA) to three consecutive years of strong LFA, } \\
\text { and who had completed at least one year of college by the end of their first year } \\
\text { of strong LFA. The definition of strong LFA is provided in section } 4.1 \text {. Sample } \\
\text { includes wages for the first three years following transition, and for any } \\
\text { subsequent year of strong LFA, up to } 10 \text { years following transition. }\end{array}$} \\
\hline
\end{tabular}


Table 5: Wage Growth and Job Changes

\begin{tabular}{|c|c|c|c|c|}
\hline Variables & Model 8 & Model 9 & Model 10 & Model 11 \\
\hline \multirow[t]{2}{*}{ Intercept } & 0.1509 & 0.0512 & -0.1369 & -0.1320 \\
\hline & $(0.0521)$ & $(0.0632)$ & $(0.1065)$ & $(0.1069)$ \\
\hline \multirow[t]{2}{*}{ Female } & -0.0042 & -0.0100 & -0.0034 & -0.0170 \\
\hline & $(0.0063)$ & $(0.0063)$ & $(0.0074)$ & $(0.0267)$ \\
\hline \multirow[t]{2}{*}{ Hours of Work } & & 0.0001 & 0.0002 & 0.0002 \\
\hline & & $(0.0000)$ & $(0.0000)$ & $(0.0000)$ \\
\hline \multirow[t]{2}{*}{$(\text { Hours of Work) })^{2}(/ 10,000)$} & & -0.0003 & -0.0003 & -0.0004 \\
\hline & & $(0.0001)$ & $(0.0001)$ & $(0.0001)$ \\
\hline \multirow[t]{2}{*}{ Job Change } & & & 0.4265 & 0.3817 \\
\hline & & & $(0.1893)$ & $(0.2023)$ \\
\hline \multirow[t]{2}{*}{ Job Change $\times$ Female } & & & & 0.0782 \\
\hline & & & & $(0.1465)$ \\
\hline \multirow[t]{2}{*}{ Age } & -0.0065 & -0.0065 & -0.0027 & -0.0025 \\
\hline & $(0.0010)$ & $(0.0009)$ & $(0.0020)$ & $(0.0021)$ \\
\hline \multirow[t]{2}{*}{ Years of Education } & 0.0029 & 0.0046 & 0.0017 & 0.0011 \\
\hline & $(0.0022)$ & $(0.0022)$ & $(0.0028)$ & $(0.0030)$ \\
\hline \multirow[t]{2}{*}{ AFQT Percentile } & 0.0001 & 0.0001 & 0.0003 & 0.0003 \\
\hline & $(0.0002)$ & $(0.0002)$ & $(0.0002)$ & $(0.0002)$ \\
\hline Sample Size & 4,887 & 4,887 & 4,282 & 4,282 \\
\hline
\end{tabular}

Standard errors in parentheses. Dependent variable is log hourly wage growth. Sample includes white men and women who are observed transitioning from one year of weak labor force attachment (LFA) to three consecutive years of strong LFA, and who had completed at least one year of college by the end of their first year of strong LFA. The definition of strong LFA is provided in section 4.1. Sample includes wages for the first three years following transition, and for any subsequent year of strong LFA, up to 10 years following transition. 